\title{
A neurotrofikus tropomiozin receptor-tirozin-kináz génfúziót tartalmazó daganatok diagnosztikai megközelítése
}

\author{
Lippai Zoltán dr. - Sápi Zoltán dr. \\ Semmelweis Egyetem, Általános Orvostudományi Kar, I. Sz. Patológiai és Kísérleti Rákkutató Intézet, Budapest
}

\begin{abstract}
A neurotrofikus tropomiozin receptor-tirozin-kináz (NTRK-) géncsalád tagjai (NTRK1, NTRK2, NTRK3) által kódolt tropomiozin receptor-tirozin-kináz fehérjék (TrkA, TrkB, TrkC) fiziológiásan elsősorban az idegsejtek fejlődéséért, éréséért, múködéséért felelősek. Az NTRK-géncsaládot érintő genetikai eltérések, melyek a leggyakrabban kromoszomális transzlokáció következtében jönnek létre, számos rosszindulatú daganat kialakulásához vezethetnek. Egyes, kifejezetten ritka daganatokban nagyon nagy gyakorisággal fedezhető fel valamelyik NTRK-fúziós gén létrejötte, mint például az infantilis fibrosarcoma, a congenitalis mesoblastos nephroma vagy a secretoros carcinoma, míg egyes gyakori daganatokban - vastagbélrák, tüdőrák - bár kisebb frekvenciával, de szintén megjelenhet. Az utóbbi időben vizsgált, rendkívül magas válaszadási aránnyal alkalmazott 'target' terápia miatt az NTRK-fúziós gének diagnosztikája még nagyobb jelentőségúvé vált. A cikk összegzi mindazokat a diagnosztikai eljárásokat s azok előnyeit, illetve hátrányait, melyeknek szerepük van az NTRK-géneltérések felderítésében, valamint ezek alapján további diagnosztikai megfontolásokat fogalmaz meg, melyek segíthetnek egy adott esetben a megfelelő diagnosztikai módszer megválasztásában.
\end{abstract}

Orv Hetil. 2020; 161(41): 1753-1763.

Kulcsszavak: daganatok, receptor-tirozin-kináz, génfúzió, diagnózis

\section{Diagnostic approach of tumors with neurotrophic tropomyosin receptor tyrosine kinase gene fusions}

The neurotrophic tropomyosin receptor tyrosine kinase (NTRK) gene family members (NTRK1, NTRK2, NTRK3), encoding tropomyosin receptor tyrosine kinase proteins (TrkA, TrkB, TrkC), physiologically, are responsible for the maturation, proliferation and maintenance of neurons. The genetic alterations of the NTRK family, mostly caused by chromosomal translocation, can lead to the development of several malignant tumors. These gene rearrangements can be detected in rare tumors, like infantile fibrosarcoma, congenital mesoblastic nephroma, secretory breast carcinoma, mammary analogue secretory carcinoma, with very high frequency, but also in very common malignancies - colorectal carcinoma, lung cancer - with relatively low incidence rate. Given the newly discovered, highly selective Trk inhibitors, used with high overall response rate, we highlight the growing importance of an appropriate diagnostic approach for tumors harboring NTRK gene alterations. This review discusses all diagnostic methods, their advantages and disadvantages, that can be used to identify NTRK gene fusions, and we make diagnostic considerations, that can help in these cases to choose the proper technique.

Keywords: tumors, receptor protein-tyrosine kinase, gene fusion, diagnosis

Lippai Z, Sápi Z. [Diagnostic approach of tumors with neurotrophic tropomyosin receptor tyrosine kinase gene fusions]. Orv Hetil. 2020; 161(41): 1753-1763.

(Beérkezett: 2020. április 14.; elfogadva: 2020. május 20.) 


\section{Rövidítések}

AKT = proteinkináz-B; ALK = anaplasticus lymphoma kináz receptor-tirozin-kináz; ATP = (adenosine triphosphate $)$ adenozin-trifoszfát; $\mathrm{BDNF}=$ (brain-derived neurotrophic factor) agyi eredetú neurotrofikus faktor; CA-125 = (cancer antigen 125 ) rákantigén-125; CDKN2A/B = (cyclin-dependent kinase inhibitor 2A) ciklindependenskináz-inhibitor - tumorszuppresszor gén; $\mathrm{CT}=$ (computed tomography) számítógépes tomográfia; DAG = diacil-glicerol; DNS = dezoxiribonukleinsav; EGFR $=$ (epidermal growth factor receptor) az epidermalis növekedési faktor receptora; ERK = (extracellular signal-regulated kinase) extracellulárisszignál-regulált kináz; IP3 = (inositol trisphosphate $)$ inozitol-trifoszfát $;$ MEK $=($ mitogen-activat ed protein kinase kinase) mitogénaktivált proteinkináz kináz; $\mathrm{mRNS}=$ (messenger RNS) hírvivő ribonukleinsav; NGF = (nerve-growth factor) idegsejt-növekedési faktor; NGS = (next-generation sequencing) újgenerációs szekvenálás; NT-3 = neurotrofin -3 növekedési faktor; NTRK = (neurotrophic tropomyosin receptor tyrosine kinase) neurotrofikus tropomiozin receptor-tirozin-kináz; $\mathrm{PI} 3 \mathrm{~K}=$ foszfatidil-inozitol-3-kináz; $\mathrm{PKC}=$ proteinkináz-C; $\mathrm{PLC}=$ foszfolipáz-C; $\mathrm{PTB}=$ (phosphotyrosine binding) foszfotirozinkötő - domén adapter fehérjéken; RAF $=$ (rapidly accelerated fibrosarcoma) rapidan gyorsuló fibrosarcoma - proteinkináz; RAS = rat sarcoma GTP-áz; RNS = ribonukleinsav; ROS1 = c-ros - receptor-tirozin-kináz; RT-PCR = (reverse transcription polymerase chain reaction) reverztranszkripciós polimeráz-láncreakció; $\mathrm{SH} 2=$ Src homológ-2 - domén adapter fehérjéken; TrkA, TrkB, TrkC = tirozin-kináz fehérjék

\section{A neurotrofikus tropomiozin receptor-tirozin-kináz (NTRK-) géncsalád}

A neurotrofikus tropomiozin receptor-tirozin-kináz (NTRK-) géncsaládhoz három gén tartozik - NTRKI ( $\mathrm{q} 23)$, NTRK2 (9q21) és NTRK3 (15q25). A három gén genetikai struktúrája egymáshoz nagyon hasonló. Mindhárom gén szerkezetében találhatók leucinban gazdag ismétlődéseket tartalmazó extracelluláris régiót, immunglobulin-szerü fehérjét, transzmembrán régiót, illetve tirozin-kinázt kódoló szakaszok. Az NTRKI-gén mintegy 21 kb hosszúságú. Az NTRK2 és NTRK3 gének 17-18-szor hosszabbak, köszönhetően az exonokat elválasztó, kivételesen nagy intronoknak. Az Ensembl genomadatbázis alapján mind ez idáig az NTRKl-gén 10, az NTRK2-gén 8, az NTRK3-gén 21 különbözó splice-variánsa került leírásra $[1,2]$.

$\mathrm{Az}$ általuk kódolt fehérjék (rendre TrkA, TrkB, TrkC) plazmamembránban elhelyezkedő receptorok. A receptorok ligandjai a neurotrofinok (idegsejtekre ható növekedési faktorok). A leggyakrabban a receptort a saját, elsődleges ligandja aktiválja. A TrkA-receptorhoz az NGF, a TrkB-receptorhoz a BDNF, a TrkC-receptorhoz az NT-3 neurotrofinok kapcsolódhatnak. Valószínúsíthető viszont, hogy az egyes neurotrofinok nem csupán egyetlen receptortípust aktiválhatnak, és az egyes receptorokhoz nemcsak egyetlen fajta neurotrofin kapcsolódhat. Ez elsősorban a sejttípustól és a ligandkoncentráció- tól függhet. A ligand kötődése után receptor-homodimerizáció, majd -autofoszforiláció következik be. Az így létrejött, foszforizált tirozint tartalmazó szakaszok mintegy kötőhelyül szolgálnak olyan adapter fehérjék számára, melyek SH2- vagy PTB-doménnel rendelkeznek. Az adapter molekulák kötődése révén egyes, már jól ismert jelátviteli utak - PI3K/AKT, RAS/MEK/ERK, PLC/ PKC - aktiválódása következik be, s ezáltal a sejtciklus szabályozásában fontos transzkripciós faktorok és gének múködése változik meg $[3,4]$ (1. ábra).

A Trk-fehérjék fontos szerepet játszanak az idegrendszer fejlődésében és múködésében. Több alapvető idegrendszeri funkció szabályozásáért felelősek, mint például a fájdalom, a termoreguláció (TrkA), a memória, a kognitív funkciók, a hangulat, az étvágy (TrkB), a propriocepció $(\operatorname{Trk} \mathrm{C})$. Fiziológiásan a központi és a perifériás idegrendszer idegsejtjei proliferációjának, differenciációjának, apoptózisának, sejtciklusának szabályozásában, szinaptikus plaszticitásának változásában, a neurodegeneráció megelőzésében van szerepük, de egyéb, nem neuronalis sejtekben és szövetekben (például monocyta, lymphocyta, keratinocyta, prosztata, here, tüdő, csont, hasnyálmirigy, simaizom) is expresszálódik a Trk-receptor valamelyik formája $[5,6]$.

\section{Az NTRK-géneket érintő aberrációk és azok megjelenése különböző daganatokban}

\section{Az NTRK-géneltérések kialakulásának ismert mechanizmusai}

Az NTRK-géneket érintő genetikai eltérések a leggyakrabban kromoszomális (intrakromoszomális vagy interkromoszomális) transzlokáció következtében jönnek létre. Közös jellemzőjük, hogy a karboxiterminális (3' vég) tirozin-kinázt kódoló domén mindig intakt marad. Ennek megfelelően a töréspont szinte bárhol lehet (bár mindkét gén esetében fóként intronok területén vannak), kivéve a tirozin-kinázt kódoló szakaszon. Mind ez idáig közel 80 gén került leírásra mint lehetséges partner az NTRK-géneket érintő fúziós gének létrejöttében (1. táblázat) [7-23]. A partnergéntől függetlenül a létrejövő fúziós gén által kódolt kiméra fehérje ligandfüggetlen, így a jelátviteli útvonal folyamatos aktivációja figyelhetó meg. A fúziós fehérje nem rendelkezik a normál-Trk-protein extracelluláris ligandkötő doménjével, így attól függetlenné válik a múködése. A legtöbb partnergén rendelkezik dimerizációs doménnel, ami folyamatos aktivációhoz vezet. Ennek következtében a sejtciklus szabályozása zavart szenved, ami tumorgenezishez vezet [13]. Érdemes megjegyezni, hogy kiméra transzkriptum nem csupán gének fúziója következtében jöhet létre, hanem szomszédos génekrôl átíródott mRNS-ek összekapcsolódása révén is [24]. Az NTRKIgén fúziós partnerei nagyobbrészt (körülbelül a $66 \%$-uk) intrakromoszomális átrendeződés következtében kerül- 


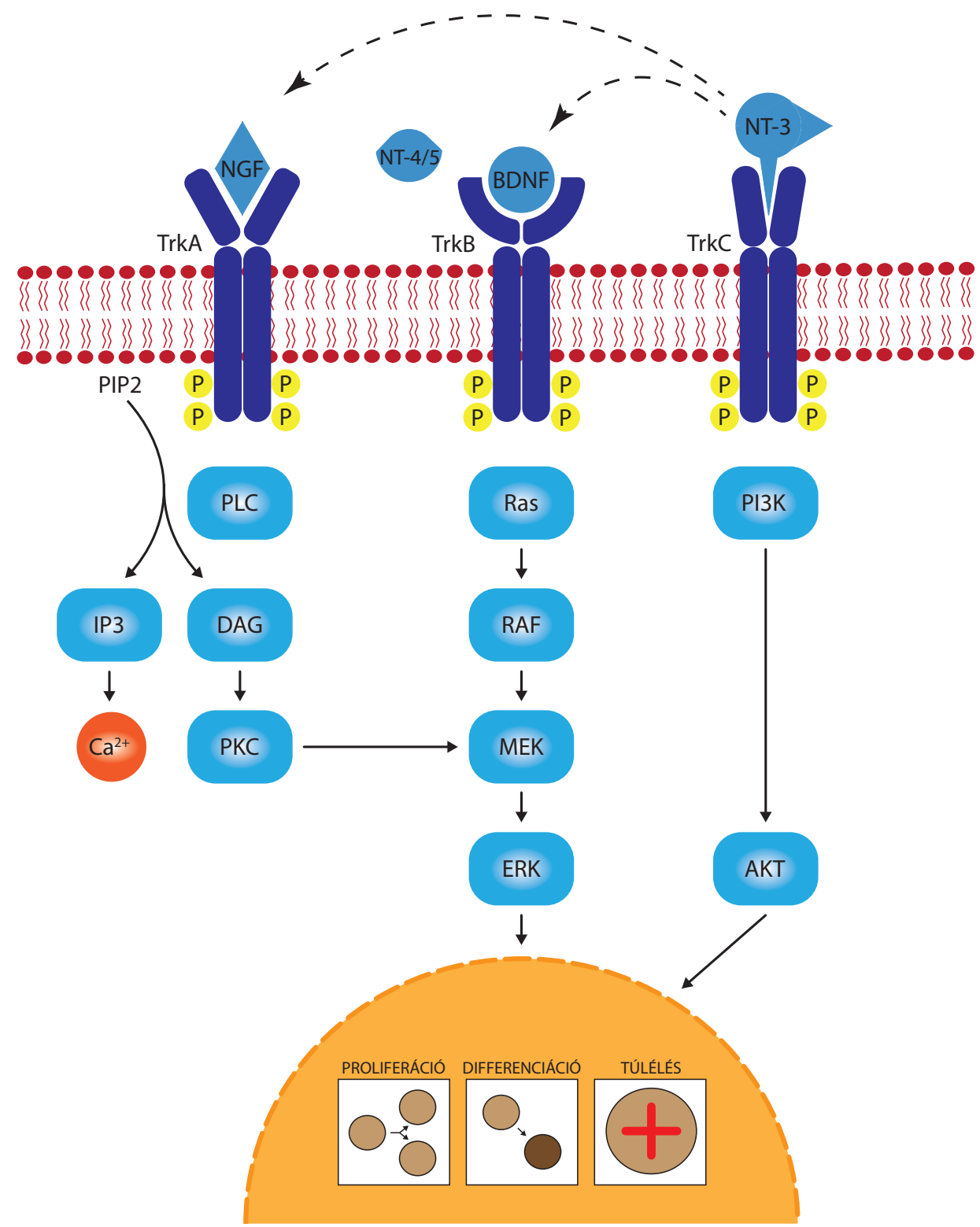

1. ábra

\begin{abstract}
A Trk-receptoroktól induló jelátviteli útvonalak
AKT = proteinkináz-B; BDNF = agyi eredetű neurotrofikus faktor; DAG = diacil-glicerol; ERK = extracellulárisszignál-regulált kináz; IP3 = inozitoltrifoszfát; $\mathrm{MEK}=$ mitogénaktivált proteinkináz kináz; NGF = idegsejt-növekedési faktor; NT-3 = neurotrofin-3 növekedési faktor; NT-4/5 = neurotrofin-4/5 növekedési faktor; PI3K = foszfatidil-inozitol-3-kináz; PIP2 = foszfatidil-inozitol-bifoszfát; PKC = proteinkináz-C; PLC = foszfolipáz-C; $\mathrm{RAF}$ = rapidan gyorsuló fibrosarcoma - proteinkináz; RAS = rat sarcoma - GTP-áz; Trk = tropomiozin receptor-tirozin-kináz; TrkA, TrkB, TrkC = tropomiozin receptor-tirozin-kináz fehérjék
\end{abstract}

nek az NTRK1-gén mellé, ellentétben az NTRK2- és az NTRK3-génnel, amelyeknél (mindkét gén esetében 70\% fölötti arányban) interkromoszomális transzlokáció révén alakul ki fúzió.

Bár a kromoszomális transzlokáció során létrejött fúzió az NTRK-géneltérések kialakulásának leggyakoribb mechanizmusa, egyéb módokat is leírtak, habár ezek klinikai relevanciája egyelöre még nem ismert pontosan. Kópiaszám-eltérések (copy number variation) figyelhetők meg számos daganattípus esetében, többek között az emlőrákok és a tüdőrákok 12\%-ában a cBioPortal adatai alapján [25]. NTRK1-amplifikációt írtak le tíz, agyi áttétekkel rendelkező emlőrákos nő közül négy esetben, ami felveti annak lehetőségét, hogy a nem megfelelően szabályozott Trk-jelátvitel fontos szerepet játszhat az áttétképződésben [26]. Egyes hasnyálmirigy-, petefészek-, nyelőcső-, húgyhólyag-, endometriumdaganatok, illetve phaeochromocytomák esetében emelkedett TrkAmRNS-szintet mértek, valószínúleg az NTRK1-gén amplifikációjából adódóan [27]. A Wilms-tumorban szenvedő betegeknél mért magasabb TrkB-mRNS-szint rövidebb, relapsus nélküli túléléssel párosult [28]. A TrkA-fehérje túltermelődését (overexpression) jobb, a TrkB-fehérje és az azt aktiváló BDNF-ligand túltermelődését rosszabb prognózisú neuroblastomában szenvedő betegeknél figyelték meg [29]. A cBioPortal adatai alap- 
1. táblázat |Az NTRK-gének leggyakoribb fúziós partnerei különböző daganatokban [7-23]

\begin{tabular}{|c|c|c|}
\hline 3' NTRK-gén & 5 ' partnergén & Daganattípusok \\
\hline \multirow[t]{7}{*}{ NTRK1 } & $L M N A$ & $\begin{array}{l}\text { Infantilis fibrosarcoma [7], Spitz-naevus/spitzoid melanoma [8], vastagbélrák [9], tüdőrák, lágyrész- } \\
\text { sarcoma }[10,11] \text {, lipofibromatosisszerú neuralis tumor [12], mellrák, cholangiocarcinoma, húgyhólyag- } \\
\text { rák, appendix-adenocarcinoma, uterussarcoma [13] }\end{array}$ \\
\hline & TPM3 & $\begin{array}{l}\text { Lipofibromatosisszerű neuralis tumor [12], tüdőrák, vastagbélrák, gyermekkori glioma [14], lágyrész- } \\
\text { sarcoma [11], papillaris pajzsmirigyrák, mellrák, méhnyakrák, cholangiocarcinoma, infantilis fibrosarco- } \\
\text { ma, uterussarcoma [13] }\end{array}$ \\
\hline & $T P R$ & $\begin{array}{l}\text { Lipofibromatosisszerü neuralis tumor [12], papillaris pajzsmirigyrák [15], tüdőrák, uterussarcoma [13], } \\
\text { gyermekkori mesenchymalis tumor }\end{array}$ \\
\hline & MPRIP & Tüdőrák [16] \\
\hline & $C D 74$ & Tüdőrák [16] \\
\hline & $B C A N$ & Glioblastoma [17] \\
\hline & TP53 & Spitz-naevus/spitzoid melanoma [8] \\
\hline \multirow[t]{8}{*}{ NTRK2 } & $V C L$ & Glioma [14] \\
\hline & $A G B L 4$ & Glioma [14] \\
\hline & SQSTMI & Glioma [17], tüdőrák \\
\hline & $G K A P 1$ & Glioma $[17]$ \\
\hline & KCDT8 & Glioma [17] \\
\hline & NOSIAP & Astrocytoma, glioma [17] \\
\hline & TBC1D2 & Glioma [17] \\
\hline & $V C A N$ & Glioma [17] \\
\hline \multirow[t]{4}{*}{ NTRK3 } & ETV6 & $\begin{array}{l}\text { Infantilis fibrosarcoma [18], congenitalis mesoblastos nephroma [19], emlő secretoros carcinomája } \\
\text { [20], nyálmirigy secretoros carcinomája [21], akut lymphoid leukaemia, akut myeloid leukaemia, } \\
\text { papillaris pajzsmirigyrák [15], glioma [14], inflammatoricus myofibroblastos tumor, mellrák, vastagbél- } \\
\text { rák, gastrointestinalis stromalis tumor, tüdőrák, melanoma, neuroendokrin tumor, sinonasalis adenocar- } \\
\text { cinoma, lágyrész-sarcoma, Spitz-naevus/spitzoid melanoma }\end{array}$ \\
\hline & EML4 & Infantilis fibrosarcoma [22, 23], congenitalis mesoblastos nephroma [22], glioma [17], pajzsmirigyrák \\
\hline & $B T B D 1$ & Glioma [14] \\
\hline & RBPMS & Pajzsmirigyrák, uterussarcoma [13] \\
\hline
\end{tabular}

NTRK = neurotrofikus tropomiozin receptor-tirozin-kináz

ján deletiók is leírásra kerültek, bár jelentőségük most még ismeretlen. Az NTRKl-gén 'in-frame' deletióját találták akut myeloid leukaemiás betegeknél [30, 31]. Olyan, az NTRKl-gén alternatív splicingja révén létrejövő mRNS-t azonosítottak neuroblastomasejtekból, amely ligandfüggetlen fehérje kialakulásához vezet [32]. Számos pontmutáció (single nucleotide variant) ismert, bár ezek közül kevés bizonyult onkogénnek. A tüdőben észlelt nagysejtes neuroendokrin carcinomák körülbelül 30\%-ában írtak le az NTRK2- vagy NTRK3-gént (tirozin-kináz-domén-régióban) érintő pontmutációt [33]. Az NTRK-géneket érintő pontmutációkat írtak le az előrehaladott pajzsmirigyrákban szenvedő betegek 9\%ában [34].

\section{Az NTRK-génaberrációk tumorokban}

Az NTRK-géneltérések előfordulási gyakorisága tumorokban egyelőre még nem pontosan ismert. Egy kutatócsoport 1272 lágyrész-daganat vizsgálata során 8 esetben tudott kimutatni NTRK1- (5) vagy NTRK3- (3) génaberrációt, DNS- és RNS-szekvenálás segítségével. Ebből a nyolc esetből hat 25 éven aluli beteg, négy 5 éven aluli gyermek volt. Továbbá a $C D K N 2 A / B$ tumorszuppresszor gén deletióját találták négy esetben a nyolcból, míg az összes vizsgált sarcomának csupán a 14\%ában volt jelen ez az eltérés [35]. Szintén DNS- és RNS-szekvenálást alkalmazva 2031 - huszonegy évesnél fiatalabb betegtől származó - daganatmintát vizsgáltak meg, s ennek során 9 (5 NTRK1, 4 NTRK3) NTRKgénfúziót találtak; mindannyiszor mesenchymalis tumor (köztük fibrosarcoma, szoliter fibrosus tumor, haemangioma, schwannoma, primitív neuroectodermalis tumor, inflammatoricus myofibroblastos tumor, dendriticus sarcoma) volt a diagnózis. Ezekben az esetekben 3 alkalommal $C D K N 2 A / B$-deletio is jelen volt [36]. Összesen 11502 különféle tumor (tüdőrák, vastagbélrák, emlőrák, glioma, lágyrész-sarcoma, pajzsmirigyrák, méhnyakrák) DNS- és RNS-szekvenálása nyomán 31 NTRKgénfúziót ( $8 \mathrm{db} N T R K 1,10 \mathrm{db}$ NTRK2, $13 \mathrm{db}$ NTRK3) detektáltak. Az 592 gén vizsgálatára alkalmas NGS-panel segítéségével az NTRK-génfúziót tartalma- 
zó daganatok 29\%-ában (9 eset) nem volt más patogén genetikai eltérés [37]. Az NTRK-géneltérések legnagyobb részét újgenerációs szekvenálással detektálják. Az egyre széleskörübb elérhetőség és használat révén mind pontosabb képet kaphatunk a valós értékekről. Egyelőre az NTRK-gént érintő változások előfordulási gyakoriságát mindezek alapján is csak becsülni tudjuk. Az összes daganat esetében körülbelül 1\% alatti incidenciáról beszélhetünk [4, 35-37].

Az NTRK-fúzióval rendelkező tumorok mind a gyermekkorban, mind a felnőttkorban jelen vannak. Az elmúlt évek kutatási eredményei alapján, arányaikat tekintve, a gyermekkori daganatok kialakulásában jelentősebb szerepe lehet az NTRK-génfúzióknak, mint a felnőttkori tumorokéban.

Az NTRK-géneltéréssel rendelkező tumorokat két nagy csoportra oszthatjuk aszerint, hogy milyen gyakran fordulnak elő egyes daganattípusoknál. Az első csoportba tartoznak azok a rendkívül ritka tumorok, melyeknél kifejezetten gyakran lehet NTRK-géneltérést detektálni. Az emló és a nyálmirigy secretoros carcinomáiban több mint 90\%-os gyakorisággal mutatható ki ETV6-NTRK3génfúzió $[20,21]$. Szintén ez a fúzió van jelen majdnem az összes congenitalis mesoblastos nephroma bizonyos altípusaiban (cellularis, kevert), de már találtak EML4NTRK3-fúziót is $[19,22]$. Az infantilis fibrosarcomák 70-90\%-ában detektálható ETV6-NTRK3-génfúzió [18]. Egyes infantilis fibrosarcomákban, melyek nem tartalmaznak ETV6-NTRK3-fúziót, leírtak LMNANTRK1-, illetve EML4-NTRK3-génfúziót is [7, 22, 23]. A nemrégiben új entitásként leírt lipofibromatosisszerű neuralis tumorok jelentős részében NTRKl-génfúzió mutatható ki [11]. A másik csoportot azok a gyakori daganattípusok alkotják, melyeknél NTRK-génaberrációt csak ritkán tudunk azonosítani. Papillaris pajzsmirigyrákokban NTRKl-fúziót állapítottak meg, több génpartnerrel is (TFG, TPR, TPM3) [15]. Sugárzásasszociált pajzsmirigyrákok esetében ETV6-NTRK3génfúziót írtak le. A gyermekkori papillaris pajzsmirigyrákok 25\%-ában találtak NTRK-génfúziót, míg a felnőttek esetében kevesebb mint 10\%-uknál [15, 37]. A gyermekkori gliomák 7\%-ában, a felnőttkori gliomák 2\%-ában találtak NTRK-fúziót [14, 17].

LMNA-NTRKl-génfúziót találtak már vastagbélrákban, tüdőrákban, melanomában, lágyrész-sarcomában, illetve a már említett, lipofibromatosisszerú neuralis tumorban [7-10, 16].

Nemrégiben került leírásra egy új, differenciálatlan uterussarcoma-variáns, mely morfológiailag fibrosarcomára hasonlít. Négy esetben sikerült NTRK1- vagy NTRK3-génfúziót detektálni, DNS-szekvenálás, RNSszekvenálás, FISH-, illetve immunhisztokémiai módszerekkel [13].

Egyes lágyrész-sarcomákban, melyek myo/haemangiopericytás mintázattal rendelkeznek, NTRK1-génfúziót mutattak ki DNS- és RNS-szekvenálással, 'breakapart' FISH-módszerrel [11].

\section{Terápiás lehetőségek az NTRK-géneltérést tartalmazó daganatokban}

Az első NTRK-gént 1986-ban fedezték fel [38], de csak az utóbbi 3-4 évben került a géncsalád a figyelem középpontjába. Ennek oka a nemrég kifejlesztett, nagy hatékonysággal alkalmazott szelektív terápia megjelenése.

A jelenkor daganatterápiájában egyre nagyobb jelentôségúvé válik a daganatok genetikai profilozása és az így detektálható támadási pontok felismerése. A genetikai eltérések (pontmutáció, inszerció, deletio, amplifikáció), mint biomarkerek, előre jelzik az onkogéncélzott terápia hatásosságát. A receptor-tirozin-kináz-gének mutációja esetén bekövetkező folyamatos jelátviteliútvonal-aktiváció gátlására tirozin-kináz-inhibitorokat fejlesztettek ki és alkalmaztak sikeresen. Például EGFR-mutációval rendelkező nem kissejtes tüdőrákok esetén az EGFR-tirozin-kináz-gátló terápia sokkal hatásosabb, mint a hagyományos kemoterápia.

Jelenleg is több Trk-inhibitort vizsgálnak fázis l. vagy fázis 2 . vizsgálatokban. Ezek vagy specifikusak a Trk-fehérjékre, vagy pedig multikináz-inhibitorként többféle tirozin-kináz múködését is gátolják. Az eddigi két legismertebb és legnagyobb tapasztalattal használt gyógyszer az entrektinib és a larotrektinib. Mindkét szer olyan, szájon át adható kis molekula, mely már nanomól-koncentrációban képes kifejteni a hatását. Mindkettő a Trk-receptorok ATP-kötőhelyét blokkolja. Ezek az ATP-kötő helyek mindhárom receptorban nagyon hasonlóak. Az entrektinib és a larotrektinib is mindhárom Trk-fehérje múködését gátolja, az entrektinib pedig további két receptor-tirozin-kinázt, a ROS1-et és az $A L K$-ot is.

Doebele és mtsai 2015-ben sikerrel alkalmaztak larotrektinibet (LOXO-101) egy LMNA-NTRK1-génfúzióval rendelkező, tüdőbe többszörösen áttétet adó, lágyrész-sarcomás betegben. A standard kemoterápia (szorafenib, epirubicin, meszna, doxorubicin) és a primer tumor (bal comb) mútéti eltávolítása után is progrediáló állapotú beteg mellkas-CT-jén már számos tüdőáttét került leírásra, a legnagyobb $7 \mathrm{~cm}$ átmérőjü volt, és a jelentős mennyiségü pleuralis fluidum következtében súlyos nehézlégzése alakult ki. Négy hónapos larotrektinibkezelés után a beteg állapota jelentősen javult (nehézlégzése megszűnt, oxigénpótlásra a továbbiakban nem szorult), CA-125-szintje rendeződött, mellkas-CT-jén szinte teljes remisszió képe ábrázolódott. Mellékhatások nem jelentkeztek. A larotrektinib in vivo eredményességét bizonyították egérbe oltott, NTRKI-fúzióval rendelkező vastagbélrákos sejtek dózisfüggő proliferációgátlásával [35].

Drilon és mtsai 55, olyan daganatos (17 különböző szövettani diagnózisú) beteget kezeltek larotrektinibbel, akikben NTRK-fúziót tudtak igazolni. Kortól és tumortípustól függetlenül kezelték őket. A vizsgálatba kerüléshez az egyetlen feltétel az NTRK-fúzió jelenléte volt. A teljes válaszadási arány $75 \%$ volt. (Két gyereknél a kezelés következtében történő tumorméret-csökkenés ré- 
vén tumoreltávolítást célzó mütétet végeztek sikeresen, mely után mindketten progressziómentesek voltak.) Egy év után a terápiára reagáló betegek 71\%-ánál folytatták még a terápiát, így az összes beteg $55 \%$-a volt progreszsziómentes. A terápiára adott válaszok függetlenek voltak a kortól, a partnergéntől, az érintett NTRK-géntől, a daganattípustól. Az összes mellékhatás 93\%-a volt grade 1. vagy grade 2. súlyosságú. Grade 3. súlyosságú nem kívánt hatás a betegek kevesebb mint 5\%-ában jelentkezett. Grade 4. vagy 5. súlyosságú mellékhatás nem volt. Nem volt olyan beteg, aki reagált a szerre, de azt le kellett volna állítani mellékhatás miatt. A stabil vagy progrediáló betegeknél a kinázdomén többféle mutációját találták, melyek szerzett rezisztenciához vezettek [39].

Az NTRK-gén tirozin-kinázt kódoló doménjében bekövetkező másodlagos mutáció szerzett rezisztencia kialakulásához vezethet. Entrektinib alkalmazása több alkalommal is dózisfüggő módon vezetett különböző másodlagos mutációkhoz. Ez azért lehet különösen fontos, mert egyes mutációk esetében a larotrektinib használata még hatékony lehet, viszont vannak olyan mutációk, me-

2. táblázat |Az NTRK-génfúzióval rendelkező daganatok esetében használható szelektív és multikináz-inhibitorok [40]

\begin{tabular}{|c|c|}
\hline Hatóanyag & 'Target' gének \\
\hline Larotrektinib & NTRK1, NTRK2, NTRK3 \\
\hline Entrektinib & NTRK1, NTRK2, NTRK3, ALK, ROS1 \\
\hline Krizotinib & NTRK1, ALK, ROS1, MET \\
\hline TSR-011 & NTRK1, NTRK2, NTRK3, ALK \\
\hline DS-6051b & NTRK1, NTRK2, NTRK3, ROS1 \\
\hline PLX7486 & NTRK1, NTRK2, NTRK3, CSF1R \\
\hline MGCD516 & $\begin{array}{l}\text { NTRK1, NTRK2, NTRK3, DDR2, MET, KIT, } \\
\text { KDR, PDGFR }\end{array}$ \\
\hline TPX-0005 & NTRK1, NTRK2, NTRK3, ALK, ROS1 \\
\hline LOXO-195 & NTRK1, NTRK2, NTRK3 \\
\hline ONO-5390556 & Nincs adat egyelöre \\
\hline Foretinib & $\begin{array}{l}\text { NTRKI, MET, KIT, FLT4, KDR, VEGFR, } \\
\text { RON, AXL }\end{array}$ \\
\hline Ponatinib & $\begin{array}{l}\text { NTRKI, ABL, FGFR, PDGFR, SRC, RET, KIT, } \\
\text { FLTI }\end{array}$ \\
\hline Nintedanib & NTRK1, NTRK2, NTRK3, PDGFR, FGFR \\
\hline Kabozantinib & $\begin{array}{l}\text { NTRK1, NTRK2, KDR, MET, RET, AXL, } \\
\text { KIT, FLT1, FLT3, FLT4 }\end{array}$ \\
\hline Lesztaurtinib & NTRK1, NTRK2, NTRK3, JAK2, FLT3 \\
\hline Merestinib & $\begin{array}{l}\text { NTRK1, NTRK2, NTRK3, MET, AXL, ROS1, } \\
\text { MKNK1, MKNK2, FL3, TEK DDR1, DDR2 }\end{array}$ \\
\hline Altiratinib & $\begin{array}{l}\text { NTRK1, NTRK2, NTRK3, MET, KDR, TIE2, } \\
\text { VEGFR2 }\end{array}$ \\
\hline
\end{tabular}

ALK = anaplasticus lymphoma kináz; FGFR = a fibroblastnövekedési faktor receptora; FLT = fms-szerü tirozin-kináz; JAK = Janus-kináz; NTRK = neurotrofikus tropomiozin receptor-tirozin-kináz; PDGFR = a thrombocytaeredetü növekedési faktor receptora; ROS = c-ros - receptor-tirozin-kináz; VEGFR = a vascularis endothelialis növekedési faktor receptora lyeknél nem. Szerzett rezisztencia már larotrektinibkezelés során is kialakult. Az egyre több alkalommal leírt szerzett rezisztencia miatt további Trk-targetált terápia kifejlesztésére lesz szükség. Ezért zajlik jelenleg második generációs Trk-inhibitorok kutatása, fejlesztése. Ezeket már többször is sikeresen alkalmazták első generációs tirozin-kináz-inhibitorok okozta másodlagos rezisztenciát mutató daganatok esetében [39-41] (2. táblázat).

Három, fázis 1-2. vizsgálat analízise alapján az entrektinib klinikailag jelentős és tartós, intracranialis laesiókat is célzó hatását és jól tolerálhatóságát állapították meg [42].

Mind az entrektinib, mind a larotrektinib jól tolerálható, kevés mellékhatást kifejtő szer. Elsősorban neuropszichiátriai mellékhatások jelentkezhetnek (fáradtság, szédülés, paresztézia, szorongás, tudatzavar), mert a Trk-receptorok fiziológiásan az idegrendszer múködésében játszanak szerepet. Ezeken kívül vérszegénység, fehérvérsejtszám-csökkenés, májenzim-emelkedés jelenhet meg nem kívánt hatásként. A legtöbb mellékhatás grade 1-2. súlyosságú. A kezelt betegek mindösszesen 5\%-ában jelentkezett grade 3-4. súlyosságú mellékhatás [40].

Az Amerikai Élelmiszer- és Gyógyszerfelügyelet (Food and Drug Administration) 2018 novemberében jóváhagyta a larotrektinib, majd 2019 augusztusában az entrektinib alkalmazását NTRK-génfúzióval rendelkező tumorokban [42]. Fontos kiemelni a tumoragnosztikus terápia jelentőségét, azaz a terápia megválasztásában nem szempont a tumor szövettani diagnózisa, csak az NTRK-géneltérés igazolása szükséges [41], ugyanakkor értelemszerúen szövettani diagnózis szükséges ahhoz, hogy elsősorban olyan daganatokat vizsgáljunk, melyekben gyakoribb az NTRK-géneltérés.

\section{A diagnosztika nehézségei}

Az NTRK-géneltérések identifikálása többféle diagnosztikai módszer alkalmazásával történhet. A leggyakrabban használt módszerek az immunhisztokémia, a fluoreszcens in situ hibridizáció (FISH), a reverztranszkripciós polimeráz-láncreakció (RT-PCR), valamint az újgenerációs szekvenálás (NGS). Az immunhisztokémia, a FISHés a PCR-módszer egyszerre csak egy (vagy kevés) biomarker vizsgálatára képes. Egyes klinikai esetekben ezek lehetnek a megfelelő a módszerek, de mindinkább háttérbe szorulnak majd az újgenerációs szekvenálás folyamatos elérhetôvé válásával. Ahogy a daganatok terápiájában egyre jelentősebbé válik a genetikai elváltozások mind pontosabb meghatározása (a felfedezett onkogén elváltozások és biomarkerek száma emelkedik), úgy lesz egyre nagyobb szükség olyan diagnosztikai eljárásokra, melyekkel egyszerre több géneltérés vizsgálata is lehetséges. Ezzel egyre több génaberráció rutindetektálása is megtörténne anélkül, hogy specifikusan kellene tesztelni egy-egy feltételezhető elváltozást, ugyanakkor a „costbenefit " szempontokat is figyelembe véve a célzott meghatározások jó része továbbra is valószínúleg megmarad (3. táblázat). 
3. táblázat |Az NTRK-génfúziók azonosításához alkalmazott laboratóriumi technikák, diagnosztikai metódusok

\begin{tabular}{|c|c|c|}
\hline Diagnosztikai módszerek & Előnyök & Hátrányok \\
\hline Immunhisztokémia & $\begin{array}{l}\text { Költséghatékony } \\
\text { Nagyon széles körben elérhetó } \\
\text { Kevés időt igényel } \\
\text { Kevés mintaanyagot igényel } \\
\text { Nem igényel különleges elókészítést } \\
\text { Fehérjeexpresszión alapul } \\
\text { Elfogadható szenzitivitás és specificitás } \\
\text { Magas negatív prediktív érték }\end{array}$ & $\begin{array}{l}\text { A vad típusú és a fúziós fehérje túltermelődése között } \\
\text { nem tud különbséget tenni } \\
\text { Álpozitív (idegszöveti, simaizomszöveti differenciáció } \\
\text { esetén) } \\
\text { Álnegatív (egyes NTRK3-fúziók esetén) } \\
\text { Egyszerre egy vagy kevés biomarker vizsgálható }\end{array}$ \\
\hline FISH & $\begin{array}{l}\text { Költséghatékony } \\
\text { Széles körben elérhető } \\
\text { Nem igényel sok időt (kevesebb mint egy hét) } \\
\text { Kevés mintaanyagot igényel } \\
\text { Elfogadható szenzitivitás (ha a töréspont az eddig } \\
\text { ismert helyen van) és specificitás } \\
\text { Töréspont-FISH során elegendő csak az egyik fúziós } \\
\text { gén ismerete }\end{array}$ & $\begin{array}{l}\text { A három NTRK-génre három különböző teszt kell } \\
\text { (egyszerre kevés biomarker vizsgálható) } \\
\text { Álpozitív (lehet, hogy a DNS strukturális eltérését nem } \\
\text { követi a funkció változása; ko-lokalizáció) } \\
\text { Álnegatív (az NTRK1-gén intrakromoszomális fúziója } \\
\text { esetén) } \\
\text { A partnergén ismeretlen marad }\end{array}$ \\
\hline RT-PCR & $\begin{array}{l}\text { Költséghatékony } \\
\text { Magas szenzitivitás és specificitás } \\
\text { Körülbelül egy hetet vesz igénybe }\end{array}$ & $\begin{array}{l}\text { RNS-alapú } \\
\text { Ismerni kell mindkét gént és a töréspontjaikat } \\
\text { A célszekvencia ismerete szükséges (nem képes új fúziós } \\
\text { génpartnereket detektálni) } \\
\text { Sokféle } 5 \text { '-fúziós génpartner lehetséges }\end{array}$ \\
\hline NGS & $\begin{array}{l}\text { Nem szükséges a partnergén ismerete } \\
\text { Képes új fúziós génpartnereket detektálni } \\
\text { Képes új töréspontokat detektálni } \\
\text { Képes egyszerre több gént vizsgálni } \\
\text { Többféle géneltérést is kimutat }\end{array}$ & $\begin{array}{l}\text { Költségigényes } \\
\text { Laboratórium-, felszerelés-, gyakorlatigényes } \\
\text { Az eredményig több mint két hét telik el } \\
\text { A DNS-alapú NGS használhatóságát az intronok } \\
\text { mérete, felépítése korlátozhatja } \\
\text { Álpozitív (a DNS strukturális eltérését nem követi a } \\
\text { funkció változása) } \\
\text { Az RNS-alapú NGS elvégzésekor jó minőségű RNS-re } \\
\text { van szükség } \\
\text { Egyes hibrid, DNS/RNS alapú NGS-eknél a partner- } \\
\text { gén ismerete is szükséges lehet }\end{array}$ \\
\hline
\end{tabular}

DNS = dezoxiribonukleinsav; FISH = fluoreszcens in situ hibridizáció; NGS = újgenerációs szekvenálás; NTRK = neurotrofikus tropomiozin receptor-tirozin-kináz; RNS = ribonukleinsav; RT-PCR = reverztranszkripciós polimeráz-láncreakció

\section{Immunhisztokémiai módszerek}

A legtöbb laboratóriumban elérhető immunhisztokémia kifejezetten olcsó és gyors, valamint alkalmazásához elegendő lehet akár egyetlen metszet. További előnyei közé tartozik, hogy nem szükséges a minta speciális előkészítése. Alkalmazásának elve azon alapul, hogy a génátrendeződés miatt a fehérje fokozottan fog expresszálódni. Mind ez idáig pan-Trk- és TrkA-antitesteket fejlesztettek ki és vizsgáltak. A pan-Trk-antitest révén mindhárom Trk-fehérje kimutatható. Hechtman és mtsai 21 olyan tumormintát vizsgáltak meg pan-Trk-antitestet használva, melyekben előtte DNS- és RNS-alapú szekvenálás segítségével NTRK-génfúziót mutattak ki. Az így megvizsgált 21 mintából 20-nál tapasztaltak pozitivitást, ami 95\%-os szenzitivitásnak felel meg. Továbbá megvizsgáltak 20 olyan mintát, melynél szekvenálással nem volt igazolható NTRK-fúzió. Mindegyik eset negatív volt immunhisztokémiai módszerrel vizsgálva, így ez a módszer 100\%-os specificitást adott [43]. Rudzinski és mtsai pan-Trk-antitestet használva 97\%-os szenzitivitást (29/30) és 98\%-os specificitást $(47 / 48)$ igazoltak. TrkA-antitestet vizsgálva 100\%-os (26/26) szenzitivitást tapasztaltak (köztük voltak olyan esetek is, amelyek NTRK2-vagy NTRK3-génfúziót tartalmaztak), de a specificitás csak $63 \%$ volt. A 49 esetből összesen 14 mintában észleltek gyenge pozitivitást, további 4 esetben pedig közepes intenzitású festődést találtak [44]. A már fentebb hivatkozott Gatalica és $m$ tsai által vizsgált 4136 tumormintából 28 esetben detektáltak NTRK-génfúziót, újgenerációs szekvenálással [37]. Ebből a 28 esetből 21 alkalommal tapasztaltak pozitivitást pan-Trk-immunhisztokémiát alkalmazva, ami csupán 75\%-os szenzitivitásnak felel meg [37]. Az NTRK3-génfúziók 45\%-a $(5 / 11)$ lett negatív pan-Trkimmunhisztokémiai módszerrel vizsgálva [37]. Abból a 4108 tumorból, melynél nem lehetett NTRK-génfúziót igazolni szekvenálással, 3942 eset immunhisztokémiai vizsgálattal is negatívnak bizonyult, ez $96 \%$-os specificitást mutat [37]. Az ETV6-NTRK3-fúzióval rendelkező tumoroknál - infantilis fibrosarcoma, congenitalis mesoblastos nephroma, secretoros carcinoma - a relatív alacsony szenzitivitás miatt a látott negatív eredmény köny- 
nyen álnegatív lehet, ezért ezekben az esetekben más módszer (például FISH) használata is szükséges. PanTrk-antitest alkalmazása 100\%-os negatív prediktív értéket mutatott 192 tumorminta vizsgálatát követően [45]. Pozitívnak ítélték az immunhisztokémiai eredményt, ha a tumorsejtek legalább 5\%-a mutatott akárcsak gyenge intenzitású festést is [45]. Összességében a pan-Trk-antitest alkalmazása alapvetően célszerúbbnek tûnik, különösen annak eldöntésére, hogy szükség van-e további vizsgálatokra.

Tekintettel arra, hogy a Trk-fehérje fiziológiásan többek között az idegszövetben és a simaizomszövetben is expresszálódik, előfordult, hogy immunhisztokémiai módszerrel pozitívnak bizonyultak olyan, egyébként NTRK-fúzió-negatív daganatok, melyek idegszöveti vagy simaizomszöveti differenciálódást mutattak, például neuroblastoma, glioma, gastrointestinalis stromalis tumor $[46,47]$.

A legtöbb, NTRK-fúzióval rendelkező daganat esetében a festődés citoplazmatikus, de már több esetben is leírták a festődés különböző subcellularis lokalizációját, a génpartnertől függően. Például az ETV6-NTRK3-fúzió esetén nukleáris (az ETV6 transzkripciós faktor, ezért a sejtmagon belül helyezkedik el), a $L M N A-N T R K I$-fúzió során perinukleáris (az $L M N A$-gén által kódolt lamin a sejtmaghártya része), a TPM-NTRK-fúzió következtében pedig sejtmembránt érintő (a tropomiozin a cytoskeleton alkotóeleme) festődés lesz látható [46]. Mindezek alapján, az érintett sejtek festődési mintázata utalhat a partnergénre.

\section{Fluoreszcens in situ hibridizáció}

Kevésbé széles körben érhető el, szintén kevés minta szükséges hozzá. Átfutási ideje általában kevesebb mint egy hét. Használható fúziós próba, illetve töréspontpróba. A fúziós próba esetén feltételeznünk kell mindkét gént, ami csak kivételes esetekben valósul meg. Például infantilis fibrosarcomában, congenitalis mesoblastos nephromábam, secretoros carcinomában ETV6NTRK3-génfúziót várunk. De már leírásra kerültek ETV6-NTRK3-fúzió-negatív esetek is. További hátránya az álpozitivitás a véletlenszerü ko-lokalizáció miatt. A töréspontpróba előnye, hogy nem kell ismernünk a partnergént. Elméletben lehet álnegatív, ha a töréspont érinti a gént, de az nem a két próba közötti szakaszon van. A FISH-módszer egyik nagy hátránya, hogy bár strukturális elváltozást ki tudunk vele mutatni, azt nem követi feltétlenül mindig funkcionális eltérés, így nem biztos, hogy az így felfedezett elváltozás lesz az oka a daganat kialakulásának. Továbbá ha mindhárom NTRKgént átfogóan meg akarjuk vizsgálni, akkor három különböző tesztre lesz szükség. A leggyakrabban az olyan ritka tumorok esetében használják, ahol az NTRK-géneltérés rendkívül gyakori.

\section{Reverztranszkripciós polimeráz-láncreakció}

Az RT-PCR olyan, RNS-alapú vizsgálat, mely a fúziós transzkriptum detektálására képes. Ehhez a teszthez szükséges tudni mindkét érintett gént és azok töréspontjait is. Például a nyálmirigy secretoros carcinomáiban ETV6(exon5)-NTRK3(exon15) fúzió található a legtöbb esetben, de nem mindig [48]. Klinikai használhatóságát korlátozza az NTRK-fúziós partnerek diverzitása és a töréspontok változatossága.

\section{Újgenerációs szekvenálás}

Az NGS-vizsgálatok a mintából nyert DNS vagy RNS segítségével akár a teljes genom, exom, transzkriptom analízisére képesek. Lehetséges olyan panel létrehozása is, amely csupán néhány gén vizsgálatára korlátozódik, és így magasabb szenzitivitás érhető el. A teljesgenomszekvenálás ehhez képest csökkent szenzitivitású, és sokkal nagyobb számítógépes analitikai forrásokat igényel. Ahogy a daganatok kezelésében egyre fontosabb a genetikai háttér mind pontosabb ismerete, annál inkább az a diagnosztikai modalitás kerül előtérbe, mely a lehető legkevesebb szövetminta felhasználásával a lehető legtöbb információt képes nyújtani. A DNS-alapú NGS-panelek fókuszálhatnak kevés vagy sok génre, teljesexom- vagy akár teljesgenom-szekvenálásra is képesek. Ezen tesztek segítségével egyszerre akár több száz gén vizsgálata történhet. Többféle géneltérés (pontmutáció, amplifikáció, deletio, inszerció, fúzió, mikroszatellita-instabilitás) is azonosítható a vizsgálat segítségével. Az NTRK2- és az NTRK3-génnek csak az exonrégiói vizsgálhatók, a töréspont viszont általában az intronrégiókban szokott lenni, így az eredmény álnegatív lehet. Összességében elmondható, hogy az NTRK2- és az NTRK3-fúzió detektálásának szenzitivitása korlátozott. Ami a specificitást illeti, itt is elmondható ugyanaz, ami a FISH-ról. A strukturális változás önmagában nem jelenti feltétlenül a funkció változását is. A DNS-alapú NGS-panelek nagy tisztaságú tumorszövetet igényelnek, és általában több mint két hét, amíg az eredményük megérkezik [49].

Az RNS-alapú NGS legfőbb korlátja maga az RNS, amely nagyon labilis. A formalinfixált, paraffinba ágyazott szövetekben az RNS degradálódik az idő előrehaladtával. Az RNS-izolálás különleges laboratóriumi körülményeket, felszerelést és nagy gyakorlatot igényel. Ennélfogva mindenképp szükséges a kinyert RNS kvantitatív és kvalitatív kontrollja. Már van olyan, RNS-alapú NGS-eljárás, amely képes detektálni génfúziót csupán az egyik gén ismeretével. Az RNS-szekvenálás előnyei a DNS-szekvenáláshoz képest többek között a kisebb szekvenálási teher (az mRNS intronokat már nem tartalmaz), a magasabb feltételezett szenzitivitás a fúziós transzkriptumok amplifikációja révén, illetve maga a tény, hogy a transzkriptumot az érintett gének és exonok alkotják; az mRNS fokozott expressziója szinte biztosan 
fokozott fehérjetermelődéshez vezet, és így a daganat kialakulásának valódi oka lehet [45].

A hibrid, DNS/RNS alapú szekvenálás során rendkívül magas szenzitivitással (98-100\%) és specificitással (96-100\%) mutatható ki fúzió, splice-variáns, inszerció, deletio, pontmutáció, kópiaszám-eltérés, de előfordulhat, hogy egyes, eddig még nem ismert fúziókat nem tud detektálni [46].

Egyes preanalitikus tényezók, legfóképp a nem megfelelő fixációs paraméterek (idő, hőmérséklet) nagy hatással lehetnek az immunhisztokémiai, illetve az RNS-, de akár a DNS-alapú vizsgálatok eredményeire is, minthogy álnegatív eredményeket adhatnak [45].

\section{Javasolható diagnosztikai algoritmus}

Figyelembe véve a nemzetközi ajánlásokat is [50], saját diagnosztikai stratégiát dolgoztunk ki. A megfelelő diagnosztikai stratégia felépítéséhez szükséges szem előtt tartani a már korábban leírt, különböző tumoroknál látott előfordulási gyakoriságokat, továbbá azt a tényt, hogy a legtöbb esetben más onkogén eltérések felderítése elkerülhetetlen lesz. Bár az ideális az lenne, ha minden esetben széles körű NGS-vizsgálat történne, ennek nincs realitása a magas költségek, a megfelelő laboratóriumi háttér és a szaktudás hiánya miatt. Azon entitásoknál, melyek jelentős hányadánál mutatható ki NTRK-fúziós gén, javasolt először pan-Trk-antitesttel immunhisztokémiai vagy töréspont-FISH-vizsgálatot végezni (a leggyakrabban az ETV6-NTRK3-fúziót feltételezve), majd annak eredményétől függően érdemes szekvenálni. A legtöbb tumor esetében, melyek Trk-expressziója alacsony, akárcsak az NTRK-fúzió incidenciája, alapvetően
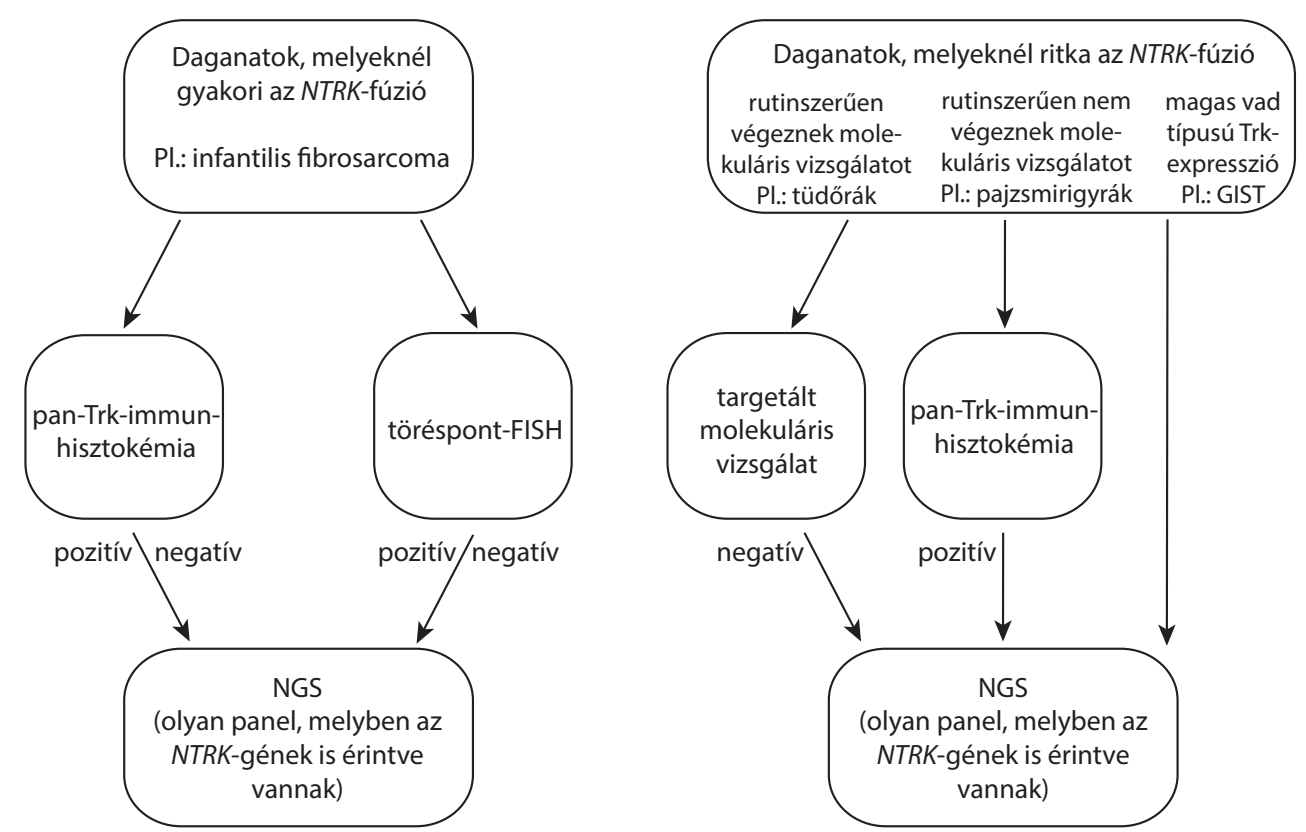

2. ábra $\quad$ Az általunk javasolt diagnosztikai algoritmus NTRK-génfúziók detektálására, figyelembe véve a nemzetközi ajánlásokat is FISH = fluoreszcens in situ hibridizáció; GIST = gastrointestinalis stromalis tumor; NGS = újgenerációs szekvenálás; NTRK = neurotrofikus tropomiozin receptor-tirozin-kináz; Trk = tropomiozin receptor-tirozin-kináz fibroblastos sarcoma esetén mintegy „elöszúrésként” lett, FISH-reakcióval ('split' próba) igazoltuk az NTRK3-gén érintettségét (3. ábra).

\section{Következtetés} néhány rendkívül ritka tumorban kifejezetten gyakori, míg számos gyakori tumorban az incidenciája $1 \%$ körül fúzió.

más targetálható onkogén eltéréseket is feltételezve széles körú NGS-vizsgálat javasolt (mely magában foglalja a nagyobb gyakoriságú feltételezett onkogéneket, de az NTRK-géneket is). Azoknál a daganatoknál, melyeknél rutinszerűen nem történik szekvenálás, ajánlatos panTrk-immunhisztokémiát végezni, és az így kiszưrt pozitív eseteket valamilyen molekuláris vizsgálatnak alávetni. Olyan tumoroknál, melyeknél a vad típusú Trk-expreszszió magasabb, mint egyéb szövetekben (neuroendokrin tumorok, gastrointestinalis stromalis tumor, agyi tumorok), az immunhisztokémia álpozitív lehet, ezért érdemes egyből molekuláris vizsgálatot végezni (2. ábra). Példaként említünk egy olyan saját esetet, amelynél myopan-Trk-immunreakciót végeztünk, és miután ez pozitív

Az NTRK-génfúzió számos daganattípusban előfordul, lehet. Az összességében alacsony incidenciájú génfúzió felismerésének jelentősége a nemrégiben kifejlesztett terápiában rejlik. A nagyon hatékonynak bizonyult szelektív tirozin-kináz-inhibitor és a többi, fejlesztés alatt álló szelektív vagy multikináz-inhibitor révén az NTRK-génfúzióval rendelkező tumorok kezelése meglehetősen ígéretesnek tûnik. A cikkben ajánlott diagnosztikai algoritmust alkalmazva a lehető leghatékonyabban találhatjuk meg azokat a daganatokat, melyekben van NTRK-gén- 


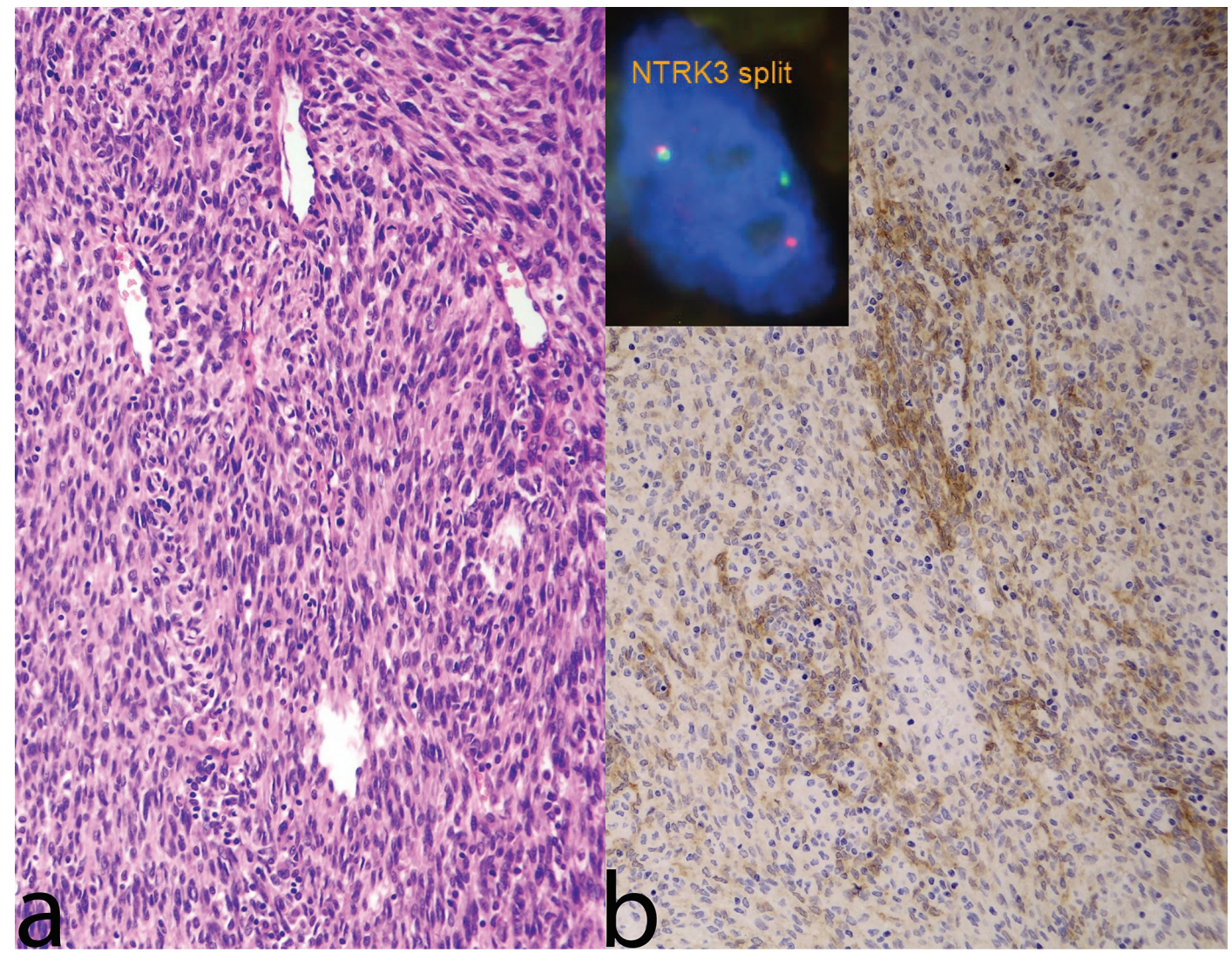

3. ábra

\footnotetext{
a) Myofibroblastos sarcoma szöveti képe, hematoxilin-eozin festés; b) pan-Trk-immunreakció egyértelmú fokális pozitív festődéssel; inzert: FISH-reakció NTRK3 split/break-apart próbával. A szignálszétválás (különálló zöld és piros szignál) jelzi, hogy NTRK3-fúzió történt, a partnergén nem ismert

FISH = fluoreszcens in situ hibridizáció; NTRK = neurotrofikus tropomiozin receptor-tirozin-kináz
}

Anyagi támogatás: A közlemény megírása anyagi támogatásban nem részesült.

Szerzői munkamegosztás: L. Z.: A szakirodalom felkutatása, elemzése, az összefoglaló közlemény megírása, a táblázatok és az ábrák elkészítése. S. Z.: A kutatás irányítása, szakértői feladat ellátása. A közlemény végleges változatát mindkét szerző elolvasta és jóváhagyta.

Érdekeltségek: A szerzőknek nincsenek érdekeltségeik.

\section{Irodalom}

[1] Chao MV. Neurotrophin receptors: a window into neuronal differentiation. Neuron 1992; 9: 583-593.

[2] Reichardt LF. Neurotrophin-regulated signalling pathways. Philos Trans R Soc Lond B Biol Sci. 2006; 361: 1545-1564.

[3] Huang EJ, Reichardt LF. Trk receptors: roles in neuronal signal transduction. Annu Rev Biochem. 2003; 72: 609-642.

[4] Vaishnavi A, Le AT, Doebele RC. TRKing down an old oncogene in a new era of targeted therapy. Cancer Discov. 2015; 5 : $25-34$.

[5] Nakagawara A. Trk receptor tyrosine kinases: a bridge between cancer and neural development. Cancer Lett. 2001; 169: 107114.

[6] Chao MV. Neurotrophins and their receptors: a convergence point for many signalling pathways. Nat Rev Neurosci. 2003; 4 : 299-309.
[7] Wong V, Pavlick D, Brennan T, et al. Evaluation of a congenital infantile fibrosarcoma by comprehensive genomic profiling reveals an $L M N A-N T R K I$ gene fusion responsive to crizotinib. J Natl Cancer Inst. 2015; 108: djv307.

[8] Wiesner T, He J, Yelensky R, et al. Kinase fusions are frequent in Spitz tumors and spitzoid melanomas. Nat Commun. 2014; 5: 3116.

[9] Sartore-Bianchi A, Ardini E, Bosotti R, et al. Sensitivity to entrectinib associated with novel LMNA-NTRKI gene fusion in metastatic colorectal cancer. J Natl Cancer Inst. 2015; 108: djv306.

[10] Kohsaka S, Saito T, Akaike K, et al. Pediatric soft tissue tumor of the upper arm with LMNA-NTRKI fusion. Hum Pathol. 2018; 72: $167-173$.

[11] Haller F, Knopf J, Ackermann A, et al. Paediatric and adult soft tissue sarcomas with NTRK1 gene fusions: a subset of spindle cell sarcomas unified by a prominent myopericytic/haemangiopericytic pattern. J Pathol. 2016; 238: 700-710.

[12] Agaram NP, Zhang L, Sung YS, et al. Recurrent NTRKI gene fusions define a novel subset of locally aggressive lipofibromatosis-like neural tumors. Am J Surg Pathol. 2016; 40: 1407-1416.

[13] Chiang S, Cotzia P, Hyman DM, et al. NTRK fusions define a novel uterine sarcoma subtype with features of fibrosarcoma. Am J Surg Pathol. 2018; 42: 791-798

[14] Wu G, Diaz AK, Paugh BS, et al. The genomic landscape of diffuse intrinsic pontine glioma and pediatric non-brainstem highgrade glioma. Nat Genet. 2014; 46: 444-450.

[15] Prasad ML, Vyas M, Horne MJ, et al. NTRK fusion oncogenes in pediatric papillary thyroid carcinoma in northeast United States. Cancer 2016; 122: 1097-1107. 
[16] Vaishnavi A, Capelletti M, Le AT, et al. Oncogenic and drug sensitive NTRKI rearrangements in lung cancer. Nat Med. 2013; 19: 1469-1472.

[17] Ferguson SD, Zhou S, Huse JT, et al. Targetable gene fusions associate with the IDH wild-type astrocytic lineage in adult gliomas. J Neuropathol Exp Neurol. 2018; 77: 437-442.

[18] Knezevich SR, McFadden DE, Tao W, et al. A novel ETV6NTRK 3 gene fusion in congenital fibrosarcoma. Nat Genet. 1998; 18: 184-187.

[19] Rubin BP, Chen CJ, Morgan TW, et al. Congenital mesoblastic nephroma $\mathrm{t}(12 ; 15)$ is associated with ETV6-NTRK3 gene fusion: cytogenetic and molecular relationship to congenital (infantile) fibrosarcoma. Am J Pathol. 1998; 153: 1451-1458.

[20] Tognon C, Knezevich SR, Huntsman D, et al. Expression of the ETV6-NTRK3 gene fusion as a primary event in human secretory breast carcinoma. Cancer Cell 2002; 2: 367-376.

[21] Skálová A, Vanecek T, Sima R, et al. Mammary analogue secretory carcinoma of salivary glands, containing the ETV6-NTRK3 fusion gene: a hitherto undescribed salivary gland tumor entity. Am J Surg Pathol. 2010; 34: 599-608.

[22] Church AJ, Calicchio ML, Nardi V, et al. Recurrent EML4NTRK3 fusions in infantile fibrosarcoma and congenital mesoblastic nephroma suggest a revised testing strategy. Mod Pathol. 2018; 31: 463-473

[23] Tannenbaum-Dvir S, Glade Bender JL, Church AJ, et al. Characterization of a novel fusion gene EML4-NTRK3 in a case of recurrent congenital fibrosarcoma. Cold Spring Harb Mol Case Stud. 2015; 1: a000471.

[24] Chwalenia K, Facemire L, Li H. Chimeric RNAs in cancer and normal physiology. Wiley Interdiscip Rev RNA 2017; 8: el427.

[25] Gao J, Aksoy BA, Dogrusoz U, et al. Integrative analysis of complex cancer genomics and clinical profiles using the cBioPortal. Sci Signal. 2013; 6: pll.

[26] Bollig-Fischer A, Michelhaugh SK, Wijesinghe P, et al. Cytogenomic profiling of breast cancer brain metastases reveals potential for repurposing targeted therapeutics. Oncotarget 2015; 6: 14614-14624.

[27] Narayanan R, Yepuru M, Coss CC, et al. Discovery and preclinical characterization of novel small molecule TRK and ROS1 tyrosine kinase inhibitors for the treatment of cancer and inflammation. PLoS ONE 2013; 8: e83380.

[28] Eggert A, Grotzer MA, Ikegaki N, et al. Expression of the neurotrophin receptor receptor TrkB is associated with unfavorable outcome in Wilms' tumor. J Clin Oncol. 2001; 19: 689-696.

[29] Brodeur GM, Minturn JE, Ho R, et al. Trk receptor expression and inhibiton in neuroblastomas. Clin Cancer Res. 2009; 15: 3244-3250

[30] Tomasson MH, Xiang Z, Walgren R, et al. Somatic mutations and germline sequence variants in the expressed tyrosine kinase genes of patients with de novo acute myeloid leukemia. Blood 2008; 111: 4797-4808.

[31] Reuther GW, Lambert QT, Caligiuri MA, et al. Identification and characterization of an activating TrkA deletion mutation in acute myeloid leukemia. Mol Cell Biol. 2000; 20: 8655-8666.

[32] Tacconelli A, Farina AR, Cappabianca L, et al. TrkA alternative splicing: a regulated tumor-promoting switch in human neuroblastoma. Cancer Cell 2004; 6: 347-360.

[33] Marchetti A, Felicioni L, Pelosi G, et al. Frequent mutations in the neurotrophic tyrosine receptor kinase gene family in large cell neuroendocrine carcinoma of the lung. Hum Mutat. 2008; 29: 609-616.

[34] Iniguez-Ariza NM, Bible KC, Morris JC, et al. NTRK1-3 point mutations in poor prognosis thyroid cancers. J Clin Oncol. 2017; 35(15_Suppl): 6087.
[35] Doebele RC, Davis LE, Vaishnavi A, et al. An oncogenic NTRK fusion in a patient with soft-tissue sarcoma with response to the tropomyosin-related kinase inhibitor LOXO-101. Cancer Discov. $2015 ; 5$ : 1049-1057.

[36] Pavlick D, Schrock AB, Malicki D, et al. Identification of NTRK fusions in pediatric mesenchymal tumors. Pediatr Blood Cancer 2017; 64: e26433.

[37] Gatalica Z, Xiu J, Swensen J, et al. Molecular characterization of cancers with NTRK gene fusions. Mod Pathol. 2019; 32: 147153.

[38] Martin-Zanca D, Hugh SH, Barbacid M. A human oncogene formed by the fusion of truncated tropomyosin and protein tyrosine kinase sequences. Nature 1986; 319: 743-748.

[39] Drilon A, Laetsch TW, Kummar S, et al. Efficacy of larotrectinib in TRK fusion-positive cancers in adults and children. $\mathrm{N}$ Engl J Med. 2018; 378: 731-739.

[40] Khotskaya YB, Holla VR, Farago AF, et al. Targeting TRK family proteins in cancer. Pharmacol Ther. 2017; 173: 58-66.

[41] Märkl B, Hirschbühl K, Dhillon C. NTRK-fusions - A new kid on the block. Pathol Res Pract. 2019; 215: 152572.

[42] Doebele RC, Drilon A, Paz-Ares L, et al. Entrectinib in patients with advanced or metastatic NTRK fusion-positive solid tumours: integrated analysis of three phase 1-2 trials. Lancet Oncol. 2020; 21: 271-282. [Correction: Lancet Oncol. 2020; 21 : e70.] [Correction: Lancet Oncol. 2020; 21: e341.] [Correction: Lancet Oncol. 2020; 21: e372].

[43] Hechtman JF, Benayed R, Hyman DM, et al. Pan-Trk Immunohistochemistry is an efficient and reliable screen for the detection of NTRK fusions. Am J Surg Pathol. 2017; 41: 1547-1551.

[44] Rudzinski ER, Lockwood CM, Stohr BA, et al. Pan-Trk immunohistochemistry identifies NTRK rearrangements in pediatric mesenchymal tumors. Am J Surg Pathol. 2018; 42: 927-935.

[45] Murphy DA, Ely HA, Shoemaker R, et al. Detecting gene rearrangements in patient populations through a 2 -step diagnostic test comprised of rapid IHC enrichment followed by sensitive next-generation sequencing. Appl Immunohistochem Mol Morphol. 2017; 25: 513-523.

[46] Solomon JP, Hechtman JF. Detection of NTRK fusions: merits and limitations of current diagnostic platforms. Cancer Res. 2019; 79: 3163-3168.

[47] Feng J, Ebata K, Hansen F, et al. TRK wild-type and fusion protein expression in solid tumors: Characterization by immunohistochemistry and in situ hybridization. Ann Oncol. 2018; 29: vi27.

[48] Skálová A, Vanecek T, Simpson RH, et al. Mammary analogue secretory carcinoma of salivary glands: molecular analysis of 25 ETV6 gene rearranged tumors with lack of detection of classical ETV6-NTRK3 fusion transcript by standard RT-PCR: report of 4 cases harboring ETV6- $X$ gene fusion. Am J Surg Pathol. 2016; 40: 3-13.

[49] Hsiao SJ, Zehir A, Sireci AN, et al. Detection of tumor NTRK gene fusions to identify patients who may benefit from tyrosine kinase (TRK) inhibitor therapy. J Mol Diagn. 2019; 21: 553571.

[50] Penault-Llorca F, Rudzinski ER, Sepulveda AR. Testing algorithm for identification of patients with TRK fusion cancer. J Clin Pathol. 2019; 72: 460-467.

(Sápi Zoltán dr., Budapest, Üllői út 26., 1085 e-mail: sapi.zoltan.dr@gmail.com)

A cikk a Creative Commons Attribution 4.0 International License (https://creativecommons.org/licenses/by/4.0/) feltételei szerint publikált Open Access közlemény, melynek szellemében a cikk bármilyen médiumban szabadon felhasználható, megosztható és újraközölhetö, feltéve, hogy az eredeti szerző és a közlés helye, illetve a CC License linkje és az esetlegesen végrehajtott módosítások feltüntetésre kerülnek. (SID_1) 